\title{
Motivation for increasing creativity, innovation and entrepreneurship. An experience from the classroom to business firms
}

\author{
Francisco G. Barroso-Tanoira \\ Faculty of Economics and Business Administration Anahuac Mayab University, Business Division, \\ Mérida, Yucatán, México \\ francisco.barrosodanahuac.mx, fbarroso_tanoiradyahoo.com.mx
}

\begin{abstract}
This study presents a program for increasing students' motivation to be creative, innovative and entrepreneurs, based on interventions in business firms for improving employee performance through the use of critical and creative thinking. Results showed that the program was effective both for workers and students, and that the most important factor to be considered for enhancing creativity, innovation and entrepreneurship is intrinsic motivation. People are more creative when they do what they like, instead of just doing what they know or what they are told to. The more creative people are, the better performance and higher productivity could be expected. This is an opportunity for educational institutions to set links with business firms and take a more active role in human and business development.
\end{abstract}

Keywords: Motivation; Business Management; Critical thinking; Creative thinking; Employee performance; Innovation; Entrepreneurship.

\section{Introduction}

In the early 2000 's, when I was a professor at a public university, I started the first day of my Organizational Behavior class with an activity for introducing ourselves. Every student was asked to say his name, place of residence and a goal in life (in this document, "he" and "his" also refer to "she" or "her"). The first one said his name, where he lived and that his goal in life was to get his major with a good grade. The second mentioned the same goal, and so the next one. When eight students mentioned the same goal, I decided to stop the activity and ask why they were repeating the same. Of course it is important to finish with a good grade, but it is more important to learn how to learn, solve problems and enjoy the learning (Peters, 2012). Besides, there are other goals in life like starting a business, getting an academic degree, joining a large and important enterprise and having a family, all within ethics and considering the human person in the center of any activity. Finally, a company must know when to reinvent, aligning everybody for a change before problems arise (Bertolini, Duncan \& Waldeck, 2015).

What happened was not the students' blame. A study in Mexico City, reported by Olivares (2015), in which there's a pre-college educational crisis that could be found in other parts of the Country, showed an insufficient level of achievement in the education stages before 
going to the University. Such an academic environment is producing employees for serving the system instead of people with critical and creative thinking competencies, able to make decisions, solve problems and create value for the organization they will be part of. And this is the way in which the school system is in many countries in the world, wasting the creative and innovative potential students (and professors) already have.

Getting back to the experience I shared at the beginning, those students only repeated what they thought their world was: getting a better grade for being hired by someone else. Although it is not bad to be hired, the bad thing is thinking that being hired is the only way for working and making a living. At least $85 \%$ of them came from families in which their parents were employees, so entrepreneurship was not a family topic. That's why it is important to foster criticism, creativity, innovation and entrepreneurship at all school levels, especially at the university. Both, the family environment and the school system, must be adequate for educating innovators and entrepreneurs.

Could we say that the best student is the one who gets the highest grades? Of course we can't. A student who gets the highest grades is the one who answered everything his professor asked. But if the professor is outdated or if he is only an academic without links with the business environment, that highest mark could mean nothing in the real labor world. This means that it is important for all professors to get involved in projects and activities and be updated all the time, having in mind that educating is not filling the students' head with knowledge. It is more than that...educating is giving those students everything they need to be what they came to the world for. In other words, the challenge is educating leaders to change society in a positive way, centered in human values. It is our duty, as professors, to help our students to be better professionals, but above all, to be better people. This way some of them might be good employees and others good entrepreneurs. If a school fails to prepare students for life and just focus on traditional classes (teaching centered) instead of real education (learning centered), the damage to society could be immense.

\subsection{Problem statement}

Motivation, creativity, innovation, leadership and tolerance to risk are entrepreneurial competencies related to fostering entrepreneurship, improving performance and achieving sustainable development (Barroso, 2012; Salinas, 2014). In companies in the region, training efforts have been addressed to increase technical competencies (those directly related to what a person in a job is expected to do) and transverse ones (those all jobs have in common including socioemotional ones, like communication, leadership and others). However, According to Aceves \& Barroso (2016), the two most important competencies to be strengthened at school beyond knowledge are conflict solving and decision making, which need critical and creative thinking to be achieved. Besides, there are students who think they are neither creative, nor innovative, and entrepreneurship is out of their scope. The result is loss of creative potential and money because of mistakes, routine, boredom and lack of opportunities for developing human capital. 
Through training, business enterprises must help employees improve their competencies and use them at work (Barroso, 2012). However, an enterprise must be similar to a school, giving employees the chance to explore, learn and develop beyond the traditional mechanical work (Resnick, 2007). As education continues along life, enterprises must educate individuals to become better employees, as well as better citizens and family members.

A job is not only something a person does for getting money. It must also be an opportunity to get a better quality of work life. But as the employee was once at school, it is important to educate future professionals since they are at the kindergarten and especially at the university. An important way for learning about conflict solving and decision making is helping students to be more creative, which could be achieved through teaching critical and creative thinking strategies. How to do it in an environment in which students learn by doing and discover new things, also learning how to learn and enjoying the experience?

It is important that students realize the importance of being creative and fostering creativity at work, instead of thinking that creativity is a pretty but useless course, only good for artists or scientist. For teaching critical and creative thinking some professors use traditional methods based on theory, which could be all right for teaching knowledge, abilities or skills, but not effective for helping students to learn how to learn, or for improving their motivation to be creative, innovative and become entrepreneurs.

Learning in a traditional class could be boring and a waste of potential motivation for students to engage in their own learning, for which constructivist methods are more effective (Peters, 2012). On the other hand, it is necessary to have programs in which students learn from direct experiences in business firms, which also open opportunities for education institutions to have links and agreements with business firms, the Government and other academic organizations. To which extent could a program in which students enhance creativity in business firms, increase their own motivation to be creative, innovative and entrepreneurs? Does employee performance improve as a consequence of such a program?

\section{$1.2 \quad$ Objective}

Testing a program for increasing students' motivation to be creative, innovative and entrepreneurs through interventions in business firms for improving workers' performance using critical and creative thinking.

Specific objectives:

- Identify the most important factors students must consider at designing an intervention for fostering creativity in business firms.

- Design activities to be included in the students' intervention program in business firms.

- Verify if there is significant difference in workers' creativity and performance as a result of the students' intervention. 
- Verify if there is a significant difference in students' motivation to creativity, innovation and entrepreneurship as a result of their intervention in business firms.

\subsection{Importance of the study}

This research is important because of the opportunity students have for using what they have learned in the "Creativity and Innovation" course, in real work situations identifying a problem, designing and implementing an intervention plan in enterprises and measuring results. Students learn through helping others (employees in this case) to explore, discover, develop and learn from their own context. On the other hand, employees could improve their performance and enjoy their job more and increase enterprise profitability, which could be translated into better working conditions, more competitive salaries, as well as lower turnover and absenteeism. Another benefit is that directors and managers will understand the importance of an environment which fosters creativity, innovation and entrepreneurship. This time six business firms were directly benefitted and the results will be used in future class programs and case studies.

Everybody wins with this intervention: the student learns through a direct involvement with real situation problems; the firm improves creativity and employees' satisfaction, and customers have the chance of getting better products and services. Besides, there could be a continuous opportunity for managers to improve performance through the help of students, which could strengthen the links between the university, the Government and business firms.

\section{Literature review}

\subsection{Creativity, critical and creative thinking}

Much has been said about creativity, its value for achieving competitiveness and face competition in this every day more complex and diverse world. To be competitive, firms need to solve their problems in an innovative way, with ideas that allow them to constantly adapt to their environment and survive. This means that creativity is a source of competitive advantage, this is, a source of differentiation in the long term or forever. However, although it is considered important, in many firms creativity is not enhanced or their directors think it is only for designers or the marketing staff (Barroso, 2012).

Creativity consists in generating new ideas and communicating them for creating value (De la Torre, 1997), or the capability for combining new and useful ideas, different to what has been done before, but appropriate to the problem or opportunity presented (Robbins \& Judge, 2013). For Robinson (2006), creativity is generating new and different ideas with value, and must be at the same level as literacy because everybody is born with it, but we have to develop it as we grow up. All humans are creative and express their creativity, so it is inherent to all human activities.

Critical thinking is an intellectual activity aimed to question, analyze or assess the structure 
and consistency of reasoning, especially those beliefs and affirmations that are normally considered true through knowledge and intelligence (Caroll, 2000), oriented to achieve a more reasoned and supported position about a topic. For the UMICH [University of Michigan] (2015), it is the process we use to reflect on, assess and judge the assumptions underlying our own and others ideas and efforts.

The term "critical" comes from "criticism", which comes from the Greek word "krinein", meaning to analyze, separate or discern. Then, critical thinking searches for clarity, accuracy, precision, evidence and equity, and for that there is an analytical and an evaluative line trying to give the individual the corresponding intellectual tools for distinguishing what is reasonable and what is not, or what is true and what is false. Fobler \& LeBlanc (1995) suggest that ideas must not be accepted just as they come, and for Caroll (2000), they must be analyzed through observation, experience, reasoning and -if necessary and possibleusing scientific methodology because the objective is going beyond subjective perspective, impressions and personal opinions.

The components of critical thinking are: (1) ideating and challenging assumptions; (2) recognizing the importance of the context; (3) imagining and exploring alternatives, and (4) develop reflective skepticism. Critical thinkers reorganize underlying assumptions, scrutinize arguments, judge ideas and the rationality of justifications comparing them to a range of varying interpretations and perspectives. According to Paul (UMICH, 2015), they achieve this through the following habits of the mind: confidence, contextual perspective, creativity, flexibility to adapt and change ideas or habits, inquisitive integrity, intuition, open mindedness and reflection

There are five phases of critical thinking (UMICH, 2015):

1) Trigger event: an unexpected happening is presented, creating surprise or discomfort

2) Appraisal: it is a period of self scrutinizing to identify and clarify the concern

3) Exploration: it is searching for ways to explain the circumstances

4) Developing alternative perspectives: it is selecting those assumptions and activities which seem the most satisfactory and congruent

5) Integration: becoming comfortable with, and acting on new ideas, assumptions and new ways of thinking

Critical thinkers must also develop the following skills, according to Scheffer \& Rubenfeld (UMICH, 2015):

1) Analyzing: it is to separate or breaking a whole into parts to discover its nature, functions and the relationship among those parts

2) Applying standards: it refers to judge according to established rules or criteria

3) Discriminating: recognizing differences and similarities among concepts and things or situations. It is also distinguishing carefully categories and ranks

4) Information seeking: searching for evidence, facts or knowledge by identifying relevant sources. It is looking for relevant information.

5) Logical reasoning: drawing inferences or conclusions supported by evidence 
6) Predicting: it is envisioning a plan and its consequences

7) Transforming knowledge: changing or converting the condition, nature, form or function of concepts among concepts.

There are different techniques for teaching critical thinking, such as mind maps, concept maps, synoptic charts, Ishikawa (fishbone) diagrams, Gantt charts and others, leading to discussions, synthesis and evaluations.

On the other hand, creative thinking is a way for looking at problems or situations from a different and fresh perspective, suggesting unorthodox situations (Businessdictionary, 2015). Creative thinking can be stimulated both by an unstructured process such as a general brainstorming session, and by a structured process such as lateral thinking. However, brainstorming is very structured when it is used as a method. According to UMICH (2015), creative thinkers consider rejecting standardized formats for problem solving, have an interest in a wide range of divergent fields, take multiple perspectives on a problem, use trial and error methods in their experimentation and are self confident. They trust their own judgement.

Creative thinkers keep track of their ideas, pose new questions and are open and receptive to new ideas, avoiding rigid and set patterns of doing things. They are updated in their fields to solve problems, read and look for the most important advances related to their activities, so they also use critical thinking techniques to process information. Engaging in creative hobbies, adopting a risk taking attitude and keeping up a good sense of humor are important aspects for being a creative thinking (UMICH, 2015).

For De la Torre (1997), the most important features for a person to be creative are: (1) sensitivity to problems, deficiencies, failure, gaps and improvements; (2) autonomy and criterion independence; (3) good self perception, (4) high level of expectations, and (5) engagement and consistency at work. Less creative individuals follow a strict plan, while more creative ones could change everything once again and again, planning solutions to problems from different points of view until they reach what they want. This means that, for being creative, there are three components needed (Robbins \& Judge, 2013): (1) competency, which means knowledge plus abilities plus attitudes in their work field; (2) creative thinking abilities, such as intelligence, independence, risk taking, self-control, tolerance to ambiguity and avoiding frustration; and (3) intrinsic motivation in the assignments, which refers to interesting, intensive and emoting work.

Critical thinking could be related to the left side of the brain (De Bono, 1994; Senge, 1995) which is the vertical o rational thinking, while creative thinking is related to the right hemisphere, which stands for intuition, creativity and lateral thinking.

\subsection{Creativity, innovation and entrepreneurship in business firms}

Creativity is a social benefit because it helps the development of the individual within a human, scientific and cultural frame (De la Torre, 1997). For Clegg \& Birch (2001), just a few business firms could survive without creativity in the market because the game today is constant change. The most evident value of creativity is that it helps those who make 
decisions understand problems and see what others can't.

As systems, business firms and other human organizations are linked through invisible connections that sometimes take years to arise and show the mutual benefits. When vision is shared, people improve performance because they want, not because they received an order to do it (Senge, 1995). That vision is usually spinning around the leader's charisma or because of a crisis. Having a shared vision fosters creativity and, at the same time, that creativity strengthens the vision. Besides, in firms where creativity is enhanced there is less employee turnover and absenteeism, employees are more satisfied and the environment is much nicer (Barroso, 2012).

Fobler \& LeBlanc (1995) suggest that, for enhancing creativity is important to implement the following, regardless the kind of organization:

a) Implement reverse thinking and enhance discussion.

b) Build a creativity inspiring environment. Nobody can buy creativity (Florida \& Goodnight, 2005), but everybody could be inspired to be creative.

c) Include emotions in the system, so people get involved.

d) Create an environment in which participants are free of worries, take risks and are not afraid of making mistakes.

e) Avoid excess of safety because that can lead to conformism.

f) Set high performance standards

g) Motivate confidence on responsibility, but without being too concerned about rules.

h) Be sure people see the results of their work. Feedback is a must.

i) Try ordinary people achieve goals and do extraordinary things.

One common mistake, according to Gámez (1998) and Barroso (2012), is that creativity is usually related to tangible results. However, there are intangible ways to be creative, like creativity in ideas, the relation among workmates, improvisation, planning, leadership and personal organization. Besides, it is important to identify and eliminate barriers to creativity. For Hellriegel \& Slocum (2004), they are:

a) Barriers to perception: not using all senses for problem solving; the difficulty for observing distant relations and not being able to distinguish between cause and effect.

b) Cultural barriers: the wish to adapt to established rules, avoid conflicts or an exaggerate focus on competition. It is also thinking that fantasy and other exploration actions are a waste of time.

c) Emotional barriers. They refer to the fear for making mistakes. They include not trusting others or accepting the first coming idea. For avoiding this, the best is enhancing lateral thinking (De Bono, 1996). 
The driver for creativity is connectivity (Johnson, 2010). Hallman, according to Rivero (2002), suggests that connectivity is a necessary condition for defining and understanding creativity. Individuals now are better connected and have the possibility for developing creativity in a faster way than before. However, for preparing a learning plan for students, the features presented must take in mind the following: (a) learning activities; (b) Characteristics of the learner; (3) the nature of materials, and (5) the criterial task, which is the aim of the activity (Center for the Study of Reading, 1980).

For Barroso (2007), even when managers think their employees are creative, they don't let them use their creativity, resulting in routine work and low motivation. Creativity is rewarded only with money (if it is rewarded) and there is limited use of creativity, but more use of power, rules and fear to change. As a result, there is fear to failure and avoidance for taking risks, which limits creativity and does not let it become innovation. Then, creativity is the foundation for innovation, which means that for being innovative, the first is being creative.

In business firms, at least in the Southeast of Mexico (Barroso, 2012), even when there are managers and directors who think their employees are creative, those employees have limited freedom to be creative and only tangible creativity is acknowledged. Power, rules, an unfavorable work environment or fear to change set limits to the employees, who perform more as executers than as thinkers. Gupta (2012) suggests that, for innovation, it is important that individuals master the following areas: (1) time management; (2) logic reasoning processes (process thinking); (3) statistic thinking, and (4) innovative thinking. Learning to innovate is not just accumulating knowledge, but getting the best of that knowledge. Then, the objective of education in innovation is preparing and empowering individuals for a faster innovation using creativity for giving value to the customer. To be significant, an innovation must be accepted by its users and be profitable. Of course, innovation could be measured with other indicators and metrics than monetary profits depending of what is innovated.

Managers acknowledge that it is necessary to have creative employees, but they are not properly prepared for this, thinking that technical competency training is enough. This training is focused on stimulating rational thinking teaching about techniques, procedures and norms. It is necessary to foster intuition through problem solving sessions using critical thinking techniques for organizing information (idea association, analogies), and creative thinking. Otherwise, employees' creative potential will be wasted. It's amazing to see that even though everybody in business firms think they know what creativity is and its importance, it is not enhanced and the human creative potential is not properly used.

Entrepreneurship is one of the main actors in national economy for any country (Salinas \& Barroso, 2016). For Ahmad \& Seymour (2008), there are some common elements that impulse people for entrepreneurship: (a) the capacity for finding and exploiting a business opportunity, and (b) intention to understand the entrepreneur's behavior. Feldman \& Bolino (2010), as well as Katz (2004), consider that the intention to become an entrepreneur depends in the individual's will because people value the possible results, economic impact and community benefits. This could be motivated by two factors: (1) the environment, and 
(2) sociodemographic and perception features. Drucker (2002) comments that successful entrepreneurs don't wait for new and creative ideas to come. Would-be innovators and entrepreneurs must go out of the firm, look, ask and listen, in a process for exploringdiscovering-learning process. Effective innovations start small and must be simple and focused, understanding the potential users' values and analyzing the information using both sides of the brain.

Family, personal economy and academic level also have influence in the process of entrepreneurship (Barroso, 2012; Salinas, 2014). Quijano (2006) agrees that productivity is affected by factors such as motivation, labor satisfaction, learning, academic level, work habits, labor environment, attitudes, feelings, decision making, conflict solution, ergonomics, management style, organizational culture. For Cequea, Rodriguez \& Núñez (2011), there are four human factors that affect performance: (1) individual; (2) group; (3) organizational, and (4) productivity. Students learn better when they are provided with the proper training and have the correct assistance over the time (Min, 2005).

There are people who think they are not creative, but everybody is. Creativity is inherent to our nature and must be, as Robinson (2006) said, treated at the same level and importance as literacy. It has its own value, as De la Torre (1997) stated, but only when it creates value and becomes innovation (Gupta, 2012), so to be innovative, the first step is fostering creativity. And if there's orientation to innovation, there will be the possibility for individuals to be entrepreneurs. We can say that the creator has an idea, the inventor makes it work, the innovator gives value to that idea and the entrepreneur takes the risk and takes it to the market, transformed into a product or service.

All those people working in business must be entrepreneurs because as the world is changing too fast, it is a deadly risk to remain doing the same. In this sense, organizations must be made to change, not simply to last, because if they adapt to change, they will last in the market as a result. So, sustainability must not be seen as an objective, but a result of constant change adaptation. Innovation and entrepreneurship aren't activities...they are ways of being, ways of living. I would say they must become values included in the company philosophy.

All of the above could be applied to students' training for being prepared for work. As Aceves \& Barroso (2016) mentioned, their success at work will be based in their socioemotional competencies, which sets the importance of leadership, teamwork, creative problem solving, communication, conflict solving and decision making. All of this need the use of creativity and critical thinking tools. The focus on work activities enhance skill improvement, confidence, build-up and metacognition (Min, 2005). For the Center for the Study of Reading (1980), feedback plays an important role in this training because students are more successful when they see the outcome of their actions and are instructed in self corrective procedures. 


\section{$3 \quad$ Methodology}

The research was focused on the students. What they did in the firms, besides the benefits for the workers and the organization, was a mean for measuring the difference in students' motivation to creativity, innovation and entrepreneurship, so there was an intervention (workers' change) within another intervention (students' change). The last one is the research object. The study is descriptive and because a comparison among groups of students was not possible because they intervened in different firms, the research had a preexperimental design (Hernández, Fernández \& Baptista, 2014), which means that the results of each group of students were compared before and after the intervention through a testretest practice, without a control group.

\subsection{Participants}

The study was performed with students from an acknowledged private university with more than three thousand students and 32 years in the South East of Mexico, which is part of a university national system in Mexico. There were 38 students enrolled in this experience, all of them registered in the Creativity and Innovation course during the August-December semester in 2014. The average age was 19 years old, 24 of them women (63.2\%). About their place of residence, eleven were foreign (four French, three Belgians, two Germans and two Dutch) who were in a student exchange program. Regarding the nationals, they were from the states of Yucatan, Campeche, Quintana Roo and Tabasco, in the South East of Mexico. This course is in the seventh semester according to the curricula, so the students are about to finish their studies. Twelve nationals are already working and studying, and all foreigners have work experience. The analysis unit was the whole group of 38 students, not the sub groups sent to each enterprise. The data was gathered in the August-December 2014 semester and reported in 2015.

\subsection{Instruments}

Questionnaire for employees Before the intervention, students applied the employees Part I of a questionnaire named ECQ (Employee's Creativity Questionnaire), which I designed for this purpose. The concept of creativity was not previously explained to the workers because it was required to know what they knew about it. The first part is the following:

Part I. General idea about creativity (pretest and post-test for employees):

1. It's difficult to be creative

2. Creativity is easy

3. Creativity is fun

4. I'm a creative person

At the end of the experience, students applied to workers Part I again (as a posttest), but also Part II:

Part II. Regarding this experience (only at the end of the intervention) 
1. It helped me realize I'm creative

2. It helped me use my creativity

3. I enjoyed this experience

4. I'm fearless about having mistakes

5. I'm more creative now than before this activity

Content and construct validity (Hernández et al., 2014) was verified by three experts in methodology, motivation and creativity, all of them with several years of experience as academics and consultants. Construct validity was verified by those experts because there were just nine items, which are too few for a factor analysis. The constructs revised in Part I were the concept of creativity in item 1 (Robbins \& Judge, 2013) and the features for a person to be creative in items 2 to 4 (De la Torre, 1997). In Part II, the constructs verified were the components of creativity in items 1 to 3 (Robbins \& Judge, 2013), eliminating barriers to creativity in item 4 (Hellriegel \& Slocum, 2004) and the results of creativity in item 5 (Gámez, 1998). For reliability, the questionnaire was applied to a random sample of 20 workers of different enterprises, with a resulting Cronbach's alfa of 0.82 for Part I, 0.83 for part II, and 0.81 for the complete instrument, so it was considered reliable. At the end there was an open section in which employees were invited to write free comments about this experience.

CCTIE questionnaire for students A questionnaire for students, named "CCTIE" (Creativity, Critical Thinking, Innovation and Entrepreneurship) was created for this study, both for pre and posttest. It was built using the critical thinking concepts of Caroll (2000), Fobler \& LeBlanc (1995) and UMICH (2005), as well as the creativity components of Robbins \& Judge (2013): competency, creative thinking abilities and intrinsic motivation. There was a question asking for the relation of all this with performance. It was divided in two sections: Section I (items 1 to 10) was for verifying if the student knew the concepts of creativity. Section II (items 11 to 30) was for verifying students' motivation for fostering creativity, innovation and entrepreneurship, based on the motivation questionnaire named "EM1" ("Escala de Motivación 1" or "Motivation Scale 1") by Álvarez (2012), but adapted to student attitude to be creative, innovative and entrepreneur. The items were the following:

1. Everyone is creative

2. Creativity improves employee performance

3. Creativity leads to innovation

4. Creativity leads to entrepreneurship

5. A good environment fosters creativity

6. High standards motivate people to be creative

7. Feedback fosters creativity and innovation

8. The most important for creativity is knowledge

9. The most important for creativity is critical thinking abilities

10. The most important for creativity is intrinsic motivation of the employee

11. I am motivated by using my creativity in my activities

12. I use my creativity for reaching the goals I need to accomplish 
13. I like projects in which I have to be creative

14. I think everyone must innovate in what they are doing

15. I do not stop until I accomplish what I have planned

16. I get motivated by challenges

17. I like things which require the maximum effort

18. When I work on a project I learn more

19. I am always aware of what I have to improve

20. I like searching for new ways of doing things

21. I like doing things without the need of someone giving orders

22. I am creative

23. I am innovative

24. I am entrepreneurship oriented

25. Critical thinking helps individuals to be more productive

26. Creative thinking helps individuals to be more productive

27. Individuals are more creative when they enjoy what they do

28. Leadership influences creativity

29. Leadership influences innovation

30. Leadership influences entrepreneurship

Content validity (Hernández et al., 2014) was verified by the same three experts who analyzed the ECQ questionnaire. When used as a pretest, construct validity was verified by factor analysis through the main components method and varimax rotation. The highest variances for factors related to creativity were Intrinsic motivation to be creative $(29 \%)$; Importance of critical thinking (23\%), Knowledge of what one's doing (15\%) and Having and environment to foster creativity, innovation and entrepreneurship (12\%), all of them standing for $79 \%$ of the total variance. Stability using Cronbach's alfa was 0.84 in Section I and 0.89 in Section II, with a total of 0.86, so the instrument was considered reliable and the pretest was accepted.

Both questionnaires were designed using a Likert scale: Totally agree (5) / Agree (4) / Indifferent (3) / Disagree (2), and Totally disagree (1). The scale for interpreting the numerical results was: 1 to $1.5=$ Totally disagree $/ 1.6$ to $2.5=$ Disagree $/ 2.6$ to $3.5=$ Indifferent $/ 3.6$ to $4.5=$ Agree, and 4.6 to $5=$ Totally agree. Open answers were grouped by frequency of appearance, organized in key ideas and categories.

\subsection{Procedure}

In the Creativity and Innovation course, two months after it started and all the theory was studied, discussed and practiced in class, students were organized in teams of five to seven members according to their availability of time, including at least one foreign student in each team. Finally, there were six teams sent to the companies (two manufacturing and four commercial ones, all of them Small-Sized). 
The students, according to the problem they detected in the companies, designed the activities to help employees develop critical and creative thinking competencies for improving their performance, become more motivated for detecting problems and solve them. In those courses the professor, the company managers and supervisors were present, and the employees were twenty as maximum in each business firm, divided in teams according to the activities. The program, designed by the author of this study, included the following steps:

1) Students answered the CCTIE questionnaire (students' pretest)

2) Students interviewed the owner, director, manager or whoever responsible for searching problems related to lack of creativity, innovation orientation or entrepreneurship.

3) Students interviewed employees (in all the firm or just a department, depending on the firm's approval) to know what they are doing and detect problems related to creativity, innovation or entrepreneurship.

4) Students applied participant employees the ECQ Part I questionnaire (employees' pretest)

5) With the result of steps 2 and 3, students designed an activity program for fostering creativity in the employees, lasting for the rest of the semester (a month minimum). It could be activities performed for some hours a week or maybe one activity in a moment and another at the end of the period. They must include in the program an explanation about what creativity is, myths, innovation, entrepreneurship, etc., as well as the program objective. The program learning activities could include creative games, dynamics and others, but not jeopardy or guessing meaning games since these activities do not foster group participation. Critical thinking strategies for handling, analyzing and reasoning must be also included.

6) At the end of the program they interviewed managers and employees again to verify if there was a change in what they were doing and if there was significant difference between their performance and other performance indicators related to the program.

7) Students applied employees the ECQ Part I (employees' posttest) and Part II questionnaire.

8) Students asked employees about innovative ideas to be implemented for improving their workplace, production or any other alternative, using what they learned in the program.

9) Students recorded all these experiences in an edited video and showed it in the final course exam day, in a maximum of 5-8 minutes per team, with some time for feedback and questions from the professor and their classmates. The film must have included at least the testimonies of three employees and their manager or supervisor. At the end of the presentation, the students shared their learnings from this experience with the rest of the class.

10) Students answered the CCTIE questionnaire again as a posttest at the end of the final presentation session (students' posttest).

11) Students were invited to go ahead and use the learnings from this experience. 
The activities designed by students for workers included the following activities, also supervised by the author of this research:

1) Prepare: Every activity (class, session or workshop) for employees had a trigger activity (games, puzzles, cases, stories). The objective was breaking the ice and preparing employees for the activity.

2) Understand: There was a period for analyzing the concern, explore circumstances. Critical thinking techniques (mind maps, synoptic charts, fish bone diagrams, Gantt charts) were used for organizing and classifying information. The idea was developing the skills mentioned by Scheffer and Rubenfeld, also quoted by UMICH (2015). The objective was that employees could understand the context situation and identify a problem to be solved.

3) Solve: Then, there was the creative thinking phase, motivating employees to look for solutions from a different, open or unorthodox points of view through the features quoted by De la Torre (1997): (1) sensitivity to problems, deficiencies, failure, gaps and improvements; (2) autonomy and criterion independence; (3) good self-perception, (4) high level of expectations, and (5) engagement and consistency at work. Brainstorming was used and the information was analyzed and organized using critical thinking techniques, using the steps for enhancing creativity suggested by Fobler \& LeBlanc (1995). The objective was to find a solution for the problem detected.

4) Action: Setting concrete action plans, indicators and procedures for monitoring the implementation process.

5) Feedback: Then, there was the feedback from the students to the employees about the process and the way in which those employees participated in the process.

One of the expected results was to enhance entrepreneurship in the employees, this is, to have initiative for taking action for improving business outcomes, based on the individual, group, organizational and performance factors, as suggested by Cequea et al. (2011).

\section{Results}

\subsection{Employees' experience}

The results were analyzed for all the workers as a whole and just to see if there was an improvement in their perception about creativity. In Part I of ECQ questionnaire, the pretest mean was 3.4 (Indifferent, $\mathrm{SD}=0.65$ ) and the posttest was 3.9 (Agree, $\mathrm{SD}=0.79$ ), which means that they didn't think they were creative, but they actually are. In Part II of ECQ, employees rated 4.4 (agree, $\mathrm{SD}=0.46$ ). Both differences were significant at $\mathrm{p}<0.05$. They totally agree that this experience helped them improving creativity and not to be afraid to make mistakes. Besides, there were some general comments written at the end of the ECQ questionnaire, ranked from most to least number of mentions: 
1) Creativity really helps me be a better employee

2) Creativity makes me more valuable for my work

3) I didn't know I was creative

4) Creativity is fun

5) Creativity helps me enjoy my job

6) We need a nicer environment to foster creativity

7) I wish we had these activities more often

There was an improvement in the employees' performance, observed in less absenteeism, more productivity and enthusiasm at work, according to supervisors' records. They also reported that there was a better environment, people were more participative at work and were looking for problems to solve. There was a sense of satisfaction in what they were doing. Of course, there was support from each business firm acknowledging (not necessarily with money) the employees for the job done, even when some employees said that the rewards were not as important as the challenge they were feeling.

\subsection{Students' experience}

For students, Section I of the CCTIE had a mean of 3.3 (indifferent, $\mathrm{SD}=1.12$ ) vs. 4.6 (Totally agree, $\mathrm{SD}=0.57$ ), which means that they are now more convinced that critical and creative thinking have a relation with employees' performance. For Section II, the mean was 4.6 (Totally agree, $\mathrm{SD}=0.87$ ) vs. 4.9 (Totally agree, $\mathrm{SD}=0.53$ ), both significant at $\mathrm{p}<0.05$, which means that even though they were highly motivated for fostering creativity, innovation and entrepreneurship, now they are more motivated to do that. General comments students wrote were, ranked from mostly mentioned:

1) I enjoyed this activity very much

2) I didn't believe how important it is to foster critical thinking and creativity

3) I'll foster creativity when I get a job or have my company

4) Everybody is creative

5) Creativity helps make more money

6) Creative employees are very valuable. Firms shouldn't let them go

7) Employees who can use and develop creativity stay longer in the job.

8) Creativity is the foundation of innovation and change

9) Creative employees are a source of competitive advantage

Students were greatly surprised to see that helping employees to organize information and be creative improved their performance at work. The organizational environment improved and there was a meaning for doing things and for attending work. It was rewarding for students to know that employees expected for their arrival and were willing to participate in the activities. 


\section{Discussion}

The five most important features mentioned by De la Torre (1997) were found here in the program, starting with sensitivity to problems, deficiencies, failures, gaps and improvements. The program was effective in this, so it could be affirmed that people are more creative and productive when they discover a problem or situation which is interesting. In the experience presented, the students felt motivated because the intervention was a challenge for them and because of the results they saw in employees after the intervention, which showed significant difference in the results for workers after the intervention, compared with those before the study. There was engagement both for the students and employees, which means that academy and real life are two sides of the same coin, and that they must be in cooperation all the time. This was also mentioned by Clegg \& Birch (2001).

As a finding, according to the factor analysis and the intervention results, the most important factors to be considered for fostering creativity are: (1) intrinsic motivation to be creative; (2) implementation of critical and creative thinking tools; (3) knowledge (intellectual capital), and (4) a good organizational environment for enhancing creativity. This matched the components of creativity presented by Robbins \& Judge (2013), but in this research, the most important one was intrinsic motivation for being creative, so motivation comes first, as it was found both for workers and students in this research. It means that people are more creative when they do what they like, instead of just doing what they know, so the first thing to do for enhancing creativity is making work interesting, challenging and with a meaning. The heart comes first, then the brain, as we can say. In all this process, as the Center for the Study of Reading (1980) suggests, feedback must be constant.

Then, according to the results, the most important for preparing students to increase their motivation to foster creativity, innovation and entrepreneurship is intrinsic motivation and immediate feedback about his actions. This is also valid for workers in business firms and sets up the importance for managers to know their employees and become real drivers for creative and innovative behavior. The more creative workers are, the better performance and productivity they could be. And, regarding the students, the more involved they are in fostering creativity in workers, the more motivated they are for enhancing creativity, innovation and entrepreneurship. It is a virtuous cycle.

This experience shows that it is possible to link the academia and business firms in an effective way through students' interventions, so there is a huge possibility for universities to help business firms improve at the same time their students learn how to learn. This also shows that enhancing critical and creative thinking improves workers' learning and helps business results increase. Delegating and empowering are also important, so giving students and employees freedom worked very well, as it was seen in this study.

It was not expected to have such a good participation of business firms, but their owners and directors gave their support and employees did it very well. There was some resistance to change expected, but it was just a little and vanished in the first days. Another finding is 
that even in those firms in which the results were not as good, compared to other ones, students were motivated because they got engaged in the intervention. The next steps could be to replicate the experience in other areas and orient management to enhance innovation, as Gupta (2012) suggests. This intervention proved to be good for helping students develop the socioemotional competencies, at is was suggested by Aceves \& Barroso (2016), especially regarding conflict solving and decision making.

\section{Conclusions}

Business firms dedicate resources for training their employees, but such training in many cases is ineffective because it is only based in technical aspects, not in transverse competencies such as teamwork, communication, leadership and critical and creative thinking. Employees are trained as executors, not as problem solvers, so it is necessary to teach them how to think critically and creatively to be managers of their own learning. On the other hand, traditional courses train students just to be students, designing projects as assignments which are often out of reality and just for getting a grade. But when students' talent is challenged through interesting real world contexts, their motivation increases and help others to learn.

As the results showed in this study, there's a positive and significant relation between the use of critical and creative thinking with performance, according to the testimony of managers. Besides, it was possible to increase students' motivation to be creative, innovative and entrepreneurs engaging them in meaningful real situations helping other people to be creative, so the Prepare-Understand-Solve-Action-Feedback intervention program was effective for this purpose, and also an opportunity for students to learn helping others to learn. So, an effective way to be creative is helping others to be creative, which means that the most creative people are those who help others to be creative. Creativity increases when it is shared and innovation is the result of that. This program is also a good example of how the universities and enterprises could be linked in a win-win relation. In this sense, this program is an innovation in student education.

Business firms must also consider training their workers to be critical and creative thinkers, for enhancing creativity and achieving innovation and entrepreneurship. They could do this hiring professional consultants or setting links with education institutions to benefit from the aid of professors and students. As creativity will also engage workers to participate and become more committed to the firm, it is important to eliminate perception barriers and implement constant training, but not only in the rational aspect.

Finally, as the first step to be creative is motivation, the starting point for a business leader is to inspire his staff to be creative, innovative and entrepreneurs. For this, a good start is educating the student to be an inspiring leader, not just a boss who prefers people to execute, helping the enterprise adapt to its environment, develop and last. Further studies will include replicating this study in other firms and contexts for longer periods in order to explore new links between universities and business results, as well as the effect of 
leadership, creativity, innovation and entrepreneurship in employee productivity.

The results are valid only for the companies participating in the study, but the program could be used in other contexts with the corresponding adaptations. The most important barrier was persuading the owners or directors to let their employees participate, but when they saw the results, those barriers vanished. And because of the short time of this intervention it could be considered a pilot program, setting the foundation of future longer periods of study to see changes in attitudes and work habits.

\section{$7 \quad$ References}

Aceves, M.A. \& Barroso, F. (2016). Competencias socioemocionales en las prácticas profesionales. Un estudio en la industria hotelera [Socioemotional Skills in Business Practice. A Study in the Hotel Industry]. Educación y Ciencia, 5(45), 34-49.

Ahmad, N. \& Seymour, R. (2008). Defining entrepreneurial activity: definitions supporting frameworks for data collection. OECD Statics working papers, 1. Retrieved Feb 20, 2016 from http://www.oecd.org/officialdocuments/publicdisplaydocumentpdf/?doclanguage=en $\& \operatorname{cote}=\mathrm{std} / \operatorname{doc}(2008) 1$

Álvarez, L. (2012). Escala de Motivación (EM1) en el modelo motivacional de McClelland [Motivation Scale (EM1) in McClelland's Motivational Model]. Redalyc Tesis Psicológica, 7. 120-143. Bogotá Colombia.

Barroso, F. (2007). La creatividad en las empresas: percepción y sugerencias para su aprovechamiento. Un estudio con directivos de empresas y trabajadores [Creativity in enterprises: perception and suggestions for its use. A study with business directors and employees]. Proceedings of the XI International Congress of the Administrative Science Academy (ACACIA). Tlaquepaque, Jalisco, Mexico. May $23^{\text {rd }}-25^{\text {th }}$.

Barroso, F. (2012). Factores y razones para desarrollar la creatividad en las empresas [Factors and reasons for developing creativity in enterprises. A study in the Southeast of Mexico] Revista de Ciencias Sociales, 18(3), 509-516.

Bertolini, M.; Duncan, D. \& Waldeck, A. (2015, December). Knowing when to reinvent. Harvard Business Review. Retrieved April 12 from https://hbr.org/2015/12/knowingwhen-to-reinvent

Businessdictionary (2015). Retrieved Feb 20, 2016 from http://www.businessdictionary.com/definition/creative-thinking.html

Caroll, R. T. (2000). Becoming a Critical Thinker. A Guide for the New Millennium. U.S.A.: Pearson Publishing.

Center for the study of reading (1980). Learning to learn: on training students to learn from experts. University of Chicago at Urbana-Champaign. Retrieved from https://www.ideals.illinois.edu/bitstream/handle/2142/17857/ctrstreadtechrepv01980 i00189_opt.pdf?sequence=1\&sa=U\&ei=JSVXU9_9GqLT8AG4roC4Dw\&ved=0CC 
0QFjAE\&usg=AFQjCNHNVAXFo_ujbffFonUgGxk_HeP17Q

Cequea, M.; Rodríguez, C. \& Núñez, M. (2011). Diseño de un instrumento para evaluar la productividad laboral en empresas del sector eléctrico venezolano [Instrument Design for Evaluating Labor Productivity in the Venezuelan Electrical Sector Enterprises]. Proceedings of the XV International Conference on Industrial Engineering and Industrial Management.

Clegg, B. \& Birch, P. (2001). Creatividad al instante [Instant creativity]. Mexico: Granica.

De Bono, E. (1994). El pensamiento lateral. Manual de la creatividad [Lateral thinking. Creativity manual]. Mexico: Editorial Paidos Mexicana.

De Bono, E. (1996). El pensamiento creativo [Creative thinking]. Mexico: Editorial Paidos Mexicana.

De la Torre, S. (1997). Creatividad y formación: identificación, diseño y evaluación [Creativity and formation: identification, design and evaluation]. México: Trillas.

Drucker, P. F. (2002, August). The Discipline of Innovation. Harvard Business Review. Retrieved on February 9, 2015, from https://hbr.org/2002/08/the-discipline-ofinnovation/ar/ 1

Feldman, C. \& Bolino, C. (2000). Career Patterns of the Self-employed: Career Motivations and Career Outcomes. Journal of Small Business Management, 19(38), 53-67.

Fobler, H. S. \& LeBlanc, S. (1995). Strategies for Creative Problem Solving. U.S.A.: Prentice Hall PTR.

Gámez, G. (1998). Todos somos creativos [We are all creative]. Barcelona: Ediciones Urano.

Gupta, P. (2012). The Innovation Solution. Making Innovation More Pervasive, Predictable and Profitable. U.S.A.: Accelper Consulting.

Hellriegel, D. \& Slocum, J. (2004). Comportamiento organizacional [Organizational behavior] (10th. Ed.). Mexico: Thomson.

Hernández, R.; Fernández, L. \& Baptista, P. (2014). Metodología de la investigación [Methodology of Research] (6th. ed.). México: McGraw-Hill.

Johnson, S. (2010). Where Good Ideas Come From. The Natural History of Innovation. New York: Riverhead Books.

Katz, J. (1994). Modeling Entrepreneurial Career Progressions: concepts and considerations. Entrepreneurship: Therory and Practice, 2(19), 23-24.

Min, Hui-Tzu (2005). Training students to become succesful peer reviewers. System, 33, 293-308. Retrieved from http://epi.sc.edu/ar/AS_4_files/Min\%202005.pdf

Olivares, E. (March 2nd, 2015). Los jóvenes llegan a la universidad sin comprender lo que leen, alerta un estudio [Young Students Arrive at College Without Understanding What They Read, Warns a Study]. La Jornada. Retrieved on March 3' 2015, from http://www.jornada.unam.mx/ultimas/2015/03/02/existe-una-crisis-educativa-en- 
formacion-preuniversitaria-en-mexico-estudio-9948.htm1

Peters, R.G. (2012). Differences Between Traditional and Progressive Education. Wingra School. Available at http://www.wingraschool.org/who/progressive.htm

Quijano, W. (2006). Dirección de recursos humanos y consultoría en las organizaciones [Human Resources Management and Consulting in Organizations]. Barcelona: Icaria Editorial, S. A.

Resnick, M. (June, 2007). All I Really Need to Know (About Creative Thinking) I Learned (By Studying How Children Learn) in Kindergarten. Proceedings of the Sixth Creativity and Cognition Conference, Washington, D.

Rivero, V. (2002). Soñar para diseñar [Dream to design] (Unpublished undergraduate dissertation). Anahuac Mayab University, Merida Yucatan Mexico.

Robbins, S. \& Judge, T. (2013). Comportamiento organizacional [Organizational behavior] ( $15^{\mathrm{a}}$ ed.). México: Pearson Prentice Hall.

Robinson, K. (2006, February). Do schools kill creativity? [Film] Retrieved June 18, 2016, from http://ed.ted.com/on/KA5cHhm8

Salinas, D. (2014). Competencias emprendedoras, motivación para emprender y productividad. Un estudio en el sureste de México [Entrepreneurship competencies, motivation for entrepreneurship and productivity. A study in the Southeast of Mexico] (Unpublished doctoral dissertation). Anahuac Mayab University, Merida Yucatan Mexico.

Salinas, D. \& Barroso, F (2016). Eficacia de un programa de incremento de la motivación para emprender y la productividad de trabajadores a un año de haberse implementado [Efficacy of a program for increasing motivation for entrepreneurship and employees productivity one year after it was implemented]. Proceedings of the I Anahuac Mayab International Research Congress in Administrative Science (ICAAM). June $1^{\text {st }}-3^{\text {rd }}$.

Senge, P. (1995). La quinta disciplina [The Fifth Discipline] ( $3^{\text {rd }}$. Ed.). Buenos Aires; Granica.

UMICH (2015). Problem Solving. Critical and Creative thinking. Retrieved from http://www.umich.edu/ elements/5e/probsolv/strategy/crit-n-creat.htm 